Cahiers $d u$ MONDE RUSSE

\section{Cahiers du monde russe}

Russie - Empire russe - Union soviétique et États indépendants

$46 / 4 \mid 2005$

L'invention d'une politique humanitaire

\title{
Sergei Bogatyrev, ed., Russia Takes Shape
}

John Keep

\section{OpenEdition \\ Journals}

Electronic version

URL: https://journals.openedition.org/monderusse/6647

DOI: 10.4000/monderusse.6647

ISSN: $1777-5388$

Publisher

Éditions de l'EHESS

\section{Printed version}

Date of publication: 1 December 2005

Number of pages: $948-951$

ISBN: 2-7132-2057-2

ISSN: $1252-6576$

\section{Electronic reference}

John Keep, "Sergei Bogatyrev, ed., Russia Takes Shape", Cahiers du monde russe [Online], 46/4 | 2005, Online since 29 June 2009, connection on 03 September 2022. URL: http://journals.openedition.org/ monderusse/6647 ; DOl: https://doi.org/10.4000/monderusse.6647

This text was automatically generated on 3 September 2022

All rights reserved 


\title{
Sergei Bogatyrev, ed., Russia Takes Shape
}

\author{
John Keep
}

\section{REFERENCES}

Sergei BOGATYREV, ed., Russia Takes Shape: Patterns of Integration from the

Middle Ages to the Present. Helsinki: Academia Scientiarum Fennica, 2004, 289 p.

(Annales Academiae Scientiarum Fennicae, Humaniora, 1239-6982 ; 335)

1 This miscellany brings together some fruits of recent research by Finnish specialists in Russian history, whose excellent work, even when published in a Western language, does not always receive sufficient attention abroad. The editor, Sergei Bogatyrev (London), who defended his doctoral thesis on sixteenth-century Muscovite court politics at the University of Helsinki in 2000, devotes this volume to the history of Russia's regions. In particular the six contributors seek to throw light on the process whereby various regions became integrated into the multi-national empire. This unifying theme is not, however, pressed too strongly and each essay may best be regarded as an independent study. A more rigorously constructed collaborative project such as this might most usefully have focussed on one of the three basic aspects of the integrating process: administrative, socio-economic or cultural; as it is, the topics treated here range over a wide compass and stretch chronologically from Kievan Rus' to the present - from Perun to Putin, so to say.

2 Jukka Korpela (Joensuu) examines the role that the canonization of saintly rulers or ecclesiastics by the Russian Orthodox Church played in consolidating Muscovite rule. He makes it clear that the choice of a candidate for sainthood, and the timing of such a decision, owed much to the political conjuncture. This was especially so during the metropolitanate of Makarii (1542-1563), who more than doubled the number of universal (Church-wide) cult figures and regularized the practice of their worship. Thereby he sought to elevate Ivan IV's claims to absolute power and to fortify his realm in the 
struggle against Catholic and Muslim foes. While the existence of such secular motives cannot be doubted, Korpela strains his argument and comes close to suggesting deliberate falsification by the ecclesiastical authorities, who manipulated historical facts and legends to bolster an essentially fraudulent, aggressive ideology - much like the Romantic historians of the 1840s or indeed twentieth-century Stalinists. "This crusade element of Russian history has remained to the present day" (p. 43). Overlooked here is the element of popular piety: sixteenth-century Russians believed in a fount of divine grace descending upon the righteous, which one might legitimately seek to direct towards worthier ("holier") places or persons. The eminent church historian A.V. Kartashev considered the political aspect of Ivan's canonization drive as "unconscious." This was perhaps too benign a view, yet a hypercritical one is risky, too. What evidence is there that devotees of local cults resented their universalization, rather than relishing the higher status obtained? Did not churchmen of the 'possessor' tendency have their grievances against the secular power, notably over monastic land? Politicization of saint-worship neither is nor was an exclusively Orthodox phenomenon. Despite these reservations one can but admire Korpela's patient detective work in establishing precisely when canonization occurred of particular individuals, not least those monks and laymen who braved adversity to further the cause of Christian civilization in Russia's far north - exploits that had little direct connection with consolidating absolutism.

Turning to Muscovite administation, in a substantial article (p.59-127) Bogatyrev examines the integrating role played by one particular category of official: the guba elders (gubnye starosty). Elected from among local service 'gentry,' their prime task was to root out bandits and bring them to justice. Earlier writers (this reviewer included) focussed on the way these men were chosen and how they did their job; but there is very little about such things here. Instead Bogatyrev treats the elders as omnicompetent functionaries performing an essential mediating function between the central power and the localities, building a viable 'communication network.' Where previous researchers stressed the conflicts and injustices inherent in highly stratified Muscovite society, the picture drawn here is one of social consensus and solidarity, even of administrative efficiency. This original interpretation, rooted in the cultural studies approach, will not convince everyone. Does it matter that co-operation between Moscow's Banditry Office and local élites took such a violent, repressive form: pursuing desperate social misfits, extracting confessions by torture, and sentencing thousands to death, usually after bodily mutilation? Denunciation was the norm and the accused had no rights. Yet here even Ivan IV's oprichnina is rationalized; scarcely a hint is given of the desolation that afflicted vast swathes of rural Russia from the 1570s onward. Bogatyrev's argument would have gained force had he explained the principle of mutual guarantee (krugovaia poruka) that underlay the election of guba elders and shown how their activities fitted in with those of the centrally appointed voivodes (voevody). Are these functionaries, too, to be seen as oiling a communication network? Yet in two valuable appendices (p. 106-127) Bogatyrev identifies the guba elders who served in the 1550s and explores their kinship links. Genealogically-minded historians may wish to track these families' careers on into the Imperial era.

4 Skipping Peter I's efforts to reform local government, which had such mixed results, Guzel Ibneeva (Kazan) tackles a more limited topic: Catherine II's journey in 1764 to the Baltic provinces that her illustrious predecessor had forcibly incorporated into his empire. The empress's personal encounter with the class-conscious German nobles who 
ran this region led her to launch a more interventionist policy designed to curb their privileges and to improve the lot of the native (Latvian, Estonian) peasants. But shortly afterwards a compromise was reached that allowed the local élites effectively to go on governing their corner of the empire virtually undisturbed for several more generations. In this light Ibneeva is surely too severe to blame Catherine for spurning 'dialogue between the Crown and its subjects' and adhering to 'the bureaucratic doctrine of enlightened absolutism" (p. 141), for this threat remained latent until the 1880s.

5 None of our authors is concerned with the key period after 1864, when Alexander II's reformist government made the most substantial effort to set up elective organs of local self-government, the zemstva and municipalities, inviting landowners, townsmen and even peasants to share the burden of providing elementary social services for the masses. To be sure, the chequered fortunes of these institutions over the next half-century is familiar territory, yet the gap is an awkward one. For without an appreciation of what was achieved then (or the changes wrought in 1917-1921) one cannot really understand the plight of the countryside under NEP. This is the subject of an interesting study (p. 142-169) by Arto Luukkanen (Helsinki), best known for his work on the Orthodox Church's fate under Soviet rule. What can secret police reports (svodki) tell us about the peasants' mood during these years (1921-1927)? The intrinsic unreliability of this source, tailor-made to the politicians' preferences, is well known. As the author rightly notes, they were "more a reflection of the fears of the ruling élite than an accurate depiction of the reality of the times" (p.166). Even so the information conveyed upwards had a certain, largely negative, effect on Party policy. By sustaining an image of ubiquitous subversion, it reinforced the Stalinists' conviction that coercion was essential to subdue the potentially counter-revolutionary smallholders, misleadingly labelled "kulaks." In this limited sense such reports served as "a tool of integration" (p. 169) into what would soon become a new imperial structure. In particular they document the increasing tension between the regime and country-dwellers in 1926-1927, brought about largely by arbitary administrative measures and higher taxes.

6 Less familiar to most readers will be the ample data presented here (p. 170-234) by Pekka Kauppela (Helsinki) on the dire impact that "modernization" has had on native peoples in four distinct regions of the Russian north: the Khanty-Mansi in the lower Ob valley; the Nentsy on the Yamal peninsula in the high Arctic; the Vorkuta area in the Komi republic; and the Kalevala district in central Karelia. In the first area oil, and in the second natural gas, have wrought havoc on the indigenous economy and life-style, but the Nentsy have survived the disruption better than the Khanty-Mansi. Their resilience stems from what A.V. Golovnev and G. Osherenko (in a work not cited here, Siberian Survival, Ithaca-London, 1999, p. 142) persuasively attribute to their "minimalist ethic that limits the need for material goods and intercultural interaction." In Vorkuta, where coal is king, the Komi are currently faring reasonably well; but this cannot be said of the wretched Karelians. In the area studied by Kauppela, iron-ore mining has led to ecological damage and socio-cultural impoverishment. The Finnish-speaking population are too demoralized even to contemplate emigration across the border. Their weakness is plausibly attributed to their relative cultural proximity to the Russians, in contrast to the (shamanistic) Siberian peoples further east. Kauppela's depressing but illuminating account is enriched by first-hand knowledge of the areas concerned and excellent maps (although not all of these have an indication of scale). 
7 In the last contribution (p. 235-266) the political scientist Hanna Smith (Helsinki) points out that paradoxically the two wars that post-Soviet Russia has fought in Chechnia have not prevented her integration into the international community, for when it came to taking firm action against Moscow all the organizations concerned (notably the EU, IMF and NATO) pulled back for fear of encouraging nationalist and isolationist tendencies. Smith's analysis has been confirmed by events since "9/11," but it remains unclear why it has been included in a volume dedicated to regional issues. Despite the editor's earnest efforts these essays do not form a coherent whole. Nevertheless each author presents important and well substantiated information. Future collaborative enterprises on this theme might well investigate the constant struggle between central and local authorities for control over scarce natural resources, which has had a major impact on state revenue and personal income distribution. 